\title{
Promoting Gender Diversity in the Classroom Through Drag
}

\section{Michael Ellis \\ International Christian University High School}

\section{Reference Data:}

Ellis, M. (2019). Promoting gender diversity in the classroom through Drag. In P. Clements, A. Krause, \& P. Bennett (Eds.), Diversity and inclusion. Tokyo: JALT.

In this paper, I reflect on the experience of introducing the topic of drag to Japanese high school EFL 1st- $(n=23)$ and 3rd-year $(n=86)$ students through the reality TV show RuPaul's Drag Race. Each step of the process is explained, from a questionnaire and minilecture on drag culture to the viewing of the show itself. Students' written responses to the class were analyzed. These indicated that students were able to understand and apply to their own lives complex concepts from the show, especially gender as a social construct, along with the importance of creativity and individuality. Based on these data, I argue that drag and its rejection of gender norms are both of interest to students and a useful content area for teaching English through a content and language integrated learning (CLIL) approach. Finally, I offer practical advice for teachers interested in showing similar material in their own classrooms.

本稿では、リアリテイ番組である『ル・ポールのドラアグレース』を通じて、英語を外国語として学習する日本人高校 1 年生 $(23$ 名) と3年生 (86名)にドラアグクイーンを紹介した経験について考察する。ドラアグ文化にまつわるアンケート、簡単な講義、実 際の番組視聴こてれらの各段階を本稿で説明する。また、学習者のリアクションペーパーを定量的かつ定性的に分析する。分 析の結果、学習者は番組を通じて、複倠な概念を理解し、実生活への適用が可能であったことを指摘する。特にジエンダーは 社会的に構筑されるものであること、および個人の創造性と個性の重要性を理解しえたことを指摘する。これらの結果から、ド ラアグとジェンダーにまつわる規範意識を捨てることは、ともに学習者にとり関心が高く、内容言語統合型学習 (CLIL) による英 語教授を行う上で有効な教材であるといえる。最後に、類似の教材を活用することに関心のある教員へ実践的なアドバイスを 提案する。

he introduction of lesbian, gay, bisexual, and transgender (LGBT) issues in the classroom is a controversial topic. Especially in Japanese junior and senior high school, there is a general uneasiness about content that encourages students to think critically about sexual orientation and gender norms. This is despite a very clear need for Japanese youth to reconsider rigid, traditional gender roles. In 2017, the World Economic Forum placed Japan 114th of 144 countries in its gender equality rankings, far behind other highly developed countries (World Economic Forum, 2017). This suggests teachers should begin addressing gender diversity and inclusivity to fight gender disparity.

Despite the popularity of the content and language integrated learning (CLIL) framework, there are many factors that may discourage teachers in Japan from tackling LGBT issues in their classrooms. Currently in Japan, there is a lack of content specialists who teach such classes and a tendency to avoid content areas that might be considered controversial (Ohmori, 2014). Language teachers may feel they are unqualified to teach LGBT content, even if they wish to. Furthermore, the pressure on teachers to choose material that is engaging and age appropriate may make them less likely to take risks with such topics.

Unfortunately, even if teachers decide to introduce LGBT content in their classes, it may be difficult to find suitable resources. Goldstein (2015) and MacDonald (2015a, 2015b) discovered a dangerous underrepresentation of LGBT people in language learning materials. This may be a result of the international use of textbooks, including in countries where being LGBT is illegal, and of teachers' personal reluctance to bring such issues to their classrooms (Nelson, 2015; Straut \& Sapon-Shevin, 2002). Thein (2013) found that even teachers who identify as LGBT or as allies worry that tackling such topics in class will divide students with differing opinions although it actually tends to bring classes together through meaningful and stimulating discussion.

When introduced carefully, LGBT education can greatly benefit all students. LGBT students benefit greatly from safe spaces at schools and visible representations of queer role models at young ages (Smolkin \& Young, 2011). Moore (2016) discovered that LGBT EFL classes helped to create an inclusive space for LGBT students to feel comfortable and speak honestly, ultimately aiding their language studies. Blackburn and Smith (2010) 
concluded that LGBT themes in L1 literature classes are an effective starting point to discuss topics of intersectionality.

An effective approach to introducing LGBT content in class may be through videos. Although cynics might consider movie days a short holiday for the lazy teacher, research indicates many benefits to the use of multimedia in the classroom. Berk (2009) identified videos as an effective tool to reach students with different ability levels and learning preferences in L1 university marketing classes. Such benefits extend to foreign language education as well as increased student engagement, more chances for authentic L2 input, and higher comprehension of the target language and content (Ismaili, 2013; Qiang, Hai, \& Wolff, 2007).

The purpose of this paper is to address the lack of research on LGBT education in Japanese high schools by offering a case study of a video class through a CLIL approach. The topic of drag was taught to students through the TV show RuPaul's Drag Race (Murray, 2009). Drag is a form of entertainment in which people dress and perform as caricatures of gender stereotypes, often of the opposite sex from that assigned at birth. RuPaul's Drag Race (Drag Race) is an American reality show in which drag queens compete in challenges such as acting, lip syncing, and creating extravagant costumes. Contestants are eliminated one episode at the time until a winner is decided and awarded the title of America's next drag superstar. Introducing students to these radical rejections of gender norms encourages them to think critically about the construct of gender and (hopefully) will lead to the promotion of inclusion and equality in Japanese classrooms. Implementation of the unit and student responses are discussed below.

\section{Methods}

Teaching Context

This study was conducted in an EFL program at a private senior high school in western Tokyo. In this program, three native English-speaking teachers follow the same syllabus, conducting the same lessons for three different 18-member classes of students simultaneously. The curriculum is designed to enhance students' communicative English abilities across the four skills, and syllabi are divided into content units. Once a semester, teachers in this program have special "movie days," unrelated to the regular English curriculum. Each teacher offers a video option and the students can select which video class they want to attend. The teachers provide students with a brief 100-word synopsis for each video to help them make their choices and a list of key vocabulary words to look up as previewing homework in order to activate schemata and provide linguistic scaffolding. Teachers are careful to provide a diverse range of videos in order to ensure that each student finds something that will engage and entertain them. This is the context in which I decided to introduce Drag Race.

\section{Materials and Procedures}

Drag Race was offered as a choice in four movie-day classes between November 2017 (to 1st-year students) and June 2018 (to 3rd-year students). I selected Season 6 Episode 4

"Shade: The Rusical" (Murray, 2014) because it is a very entertaining episode with highly talented queens. The episode serves as an effective introduction to drag by explaining various drag genres in the format of a musical. Because this episode was relatively early in the season, I hoped that students might be interested in watching other episodes and even other seasons in their own time. The class began with a true/false questionnaire, then a short lecture on drag was given before watching the (40-minute) video. The vocabulary list with Japanese translations for this episode is in Figure 1.

\begin{tabular}{|ll}
\hline drag queen & 女性の姿でパフォーマンスを行う男性、ドラッグクイーン \\
pageant queen & ミス・コンテストに出るような、見た目が素敵なドラッグクイーン \\
comedy queen & お笑いのセンスがあるドラッグクイーン \\
butch queen & 男っぽいドラッグクイーン \\
fishy queen & 女だと勘違いされるぐらい、女性らしいドラッグクイーン \\
(v) throw shade / be shady & 小馬鹿にする、ディスる \\
(n) shade & 小馬鹿にすること、ディスること \\
lip sync & ロパク(をする)
\end{tabular}

Figure 1. Drag Race vocabulary list.

The purpose of the true/false questionnaire was to activate schemata and gauge student perceptions about drag. The following statements were presented in English and Japanese to the students:

1. All drag queens are gay.

2. All drag queens want to be women.

3. All drag queens want to look like women.

4. All drag queens are men.

5. All drag queens do drag to make money. 
In the minilecture I used PowerPoint slides to briefly highlight counterexamples to each statement, all of which are false:

1. Not all drag queens are gay; some are heterosexual, bisexual, asexual, pansexual, and so on.

2. Not all drag queens want to be women; some are women, but most are cisgender men who perform female gender as a hobby or job.

3. Though many do, not all want to look like women, and others aim for androgyny or perform femininity to an extreme beyond most women.

4. Not all drag queens are men; cisgender women can be drag queens too, as can transgender women and nonbinary individuals. Drag also includes a subset of drag kings-people (usually women) who perform exaggerated masculinity.

5. Not all drag queens do drag to make money. Those who can make a living doing drag are lucky, but drag is expensive and often done purely as an art form or entertainment.

After the lecture, students watched the episode for the remainder of the class in English with English subtitles. Due to time restraints, there was no structured English discussion task during class. For homework, students were required to complete a response paper that included a survey on drag with Likert-style answers and a short essay of 120 words or more. The following questions were provided to guide students' responses:

1. Did you enjoy the show? Why or why not? Which parts?

2. Did this show change your opinion of drag queens? If so, how?

3. Did you have a favorite queen, or type of queen? Who? Why?

4. Do you think Japanese people could learn something from this show? What?

5. Could this show become popular in Japan? Why or why not?

6. Was there something you didn't understand from the show? What was that?

There were two things I wanted to determine from their answers: first whether students were able to understand the show and drag culture and second whether they were able to enjoy it. Analysis of student responses is discussed in the following section.

\section{Findings and Discussion}

\section{Quantitative Analysis}

First I wanted to gauge the popularity of the video and the topic of drag. I collected data on the number of students who chose Drag Race over the other movie options. This is summarized in Table 1.

Table 1. Popularity of Drag Race Among the Three Movie Day Options $(N=198)$

\begin{tabular}{lc}
\hline Date and class & Students who chose Drag Race (\%) \\
\hline November 2017, 1st-year A-set & 27 \\
November 2017, 1st-year B-set & 22 \\
June 2018, 3rd-year A-set & 91 \\
June 2018, 3rd-year B-set & 76 \\
Total (average) & 55 \\
\hline
\end{tabular}

Drag Race was more popular in the second (June) round than in the first (November). It is possible that this had to do with word of mouth-students recommended the show to their upper classmates. However, I feel this difference was largely due to the varying appeal of the other choices. In the first round of classes, the other two options were two episodes of cartoon comedies and a documentary about dinosaurs. The comedies were the most popular choice (65\% of students), and Drag Race was second (25\%). In the next round of classes, the other options were a documentary about travel in the Philippines or a documentary about dogs. In this case, Drag Race was the most popular (83\%).

The number of students who chose Drag Race appeared to be dependent on the other available choices, so it cannot be stated with certainty that drag is a topic of interest for these students, but the numbers indicate that it was not the least interesting topic. In total, 109 of 198 students chose Drag Race, and their learning outcomes are analyzed below.

Table 2 provides a summary of student responses to the questionnaire. It is interesting to note that more than half of the students believed each myth to be true. These gaps in knowledge about drag, along with the interest expressed in Table 1, suggest that drag is a fertile topic for CLIL classes. The most commonly held myths that all drag queens are gay and do drag to make money might be indicative of Japanese drag culture, in which 
highly visible queens like Matsuko Deluxe and Mitz Mangrove are some of the highest paid celebrities on television. From this, it may be necessary to bring an international perspective to classes like this in order to clarify that Japan is just one small part of LGBT culture.

Table 2. Questionnaire: Drag Myths ( $N=109)$

\begin{tabular}{lc}
\hline Myth & Students who believed it was true (\%) \\
\hline All drag queens are gay. & 80 \\
All drag queens want to be women. & 77 \\
All drag queens want to look like women. & 60 \\
All drag queens are men. & 51 \\
All drag queens do drag to make money. & 81 \\
\hline
\end{tabular}

Note. Answers from 1st- $(n=23)$ and 3rd- $(n=86)$ year high school students.

Student responses to the postviewing survey questions are summarized in Table 3. These responses indicate that students became more interested in drag and felt they learned something by watching the show. Furthermore, responses indicated that students wanted to recommend the show to others and watch more of it on their own suggesting that this could lead to more English input outside of class. Though these numbers are encouraging, they only offer a general interpretation of how students viewed this lesson. Individual student responses are examined in the following section to evaluate learning outcomes.

Table 3. Responses to Postviewing Survey Questions ( $N=109)$

\section{Question}

1) Were you interested in drag before watching the show?

2) Are you interested in drag after watching the show? (now)

3) Do you feel you understand drag better thanks to the show?

4) Would you recommend this show to your classmates?

5) Would you like to watch more of this show?

Note. Answers were on a 5-point scale: $1=$ strong no, $5=$ strong yes. Answers from 1st- $(n=23)$ and 3rd- $(n=86)$ year high school students.

\section{Student Written Responses}

All 109 students submitted a written response. The length of responses varied greatly, ranging from 120 to 604 words. Common points in their answers were a high level of interest in drag, accurate usage of the target language, and a complex conceptual understanding of themes from the show. Some of the results for each of these topics are presented below. All student responses are unedited and are in the original, errors included.

\section{High Level of Interest}

One 3rd-year student wrote, "People who were on this show were beautiful and interesting, so I started to be interested in drag. At first, I was going to study while I was watching this show, but I couldn't do that." At least one student who chose Drag Race as the best of three options may have been converted into a fan by the show. This sentiment is echoed by a 1st-year student who wrote, "I was interested in Gia Gunn, a Japanese man. ${ }^{1}$ He was born in America. He was talking about kabuki, Japanese traditional dance, and his real name is Gia Kotaro Ichikawa. I think this is so interesting because Ichikawa is the most famous kabuki family in Japan." Although Gia's background in kabuki was briefly discussed in the show, her boy name was never stated. The student did outside research after the class and ended up teaching me, a fan of the show, something even I did not know at the time. This demonstrates a high level of motivation to learn more about the target content.

\section{Use of Target Language}

Initially, I worried whether students would be able to understand the drag jargon used in the show. One 1st-year student wrote, "I thought those drag queens were more soft. However, in this show, they were in a competition, so sometimes they were shady to each other." His accurate use of the word shady, meaning playfully disrespectful, demonstrates that he did not only passively understand the target language but was also able to actively use it correctly. Another student, a weak writer, wrote her first-ever perfectly organized paragraph with the topic sentence, "I like fishy queens the best of all drag queens for several reasons." These two examples highlight the effectiveness of using topics like drag to teach English and suggest that this class was a successful example of CLIL. 


\section{Conceptual Understanding}

Other students focused on deeper concepts in their responses. One 1st-year student wrote, "I was prejudiced against men's transvestism because I thought it was little unpleasant. But, my opinion was wrong. ... Their transvestisms were individual and creative.... Then I thought everyone could change their appearance as they wanted to be." This acknowledgement of gender as a social construct from someone who selfidentified as prejudiced before watching the show is a big accomplishment. From this it appears that students were able to understand not only the language but also the themes of the show. Another 1st-year student wrote, "They all have confidence in theirselves. Though, they are minority, but they are proud that they are gay and they establish their own way of life. I thought it is not so big problem to be different from people." The concepts of pride in differences and individuality were not stated explicitly in this episode, but the fact this student was able to pick up on this indicates the content is not too complex or mature for high school students. After the completion of this unit, there were three events that provided insight into long-term learning outcomes.

\section{Parent Reactions}

In the lesson following the movie day, two students told me about sharing the contents of the class with their families. The parents of one student were supportive; the parents of the other were not. However, through conversation with their daughter, the latter students' parents accepted the value of learning about LGBT issues in school. Though only one isolated example, this illustrates CLIL classes on gender and inclusion can have a domino effect in starting conversations about taboo topics.

\section{Coming Out}

Several months after this lesson, one of the students felt comfortable enough to come out to her peers as queer in a group discussion completely separate from this unit. Though a cause and effect relationship between this instance and the Drag Race class cannot be stated strongly, it can at least be proposed that the class made this student feel that her school was a safe space to discuss such issues openly. By this logic, all students, even the 89 students who did not choose to watch Drag Race, may have been affected positively by its inclusion in the curriculum.

\section{Interviewing a Local Queen}

One student, whom I had never taught personally, approached me after class to tell me how much of a fan of the show she was and that she was studying LGBT issues as part of a graduation thesis project. The student and I went through all of the proper channels to have an excursion to a gay activist and drag queen's book café approved for her and her research partner in the summer of 2018. Through interviews with this activist and some customers, this student could improve the quality of her research and deliver a powerful message to the entire student body of 750 students: "Recently there is a trend to give LGBTQ people special treatment, but that isn't actually the goal of queer activists. We came to the conclusion that it is better to create a world in which being LGBTQ is natural and commonplace." This statement reflects a highly nuanced and complex understanding of allyship. The fact that she could deliver this message to such a large audience as a result of my decision to offer Drag Race as a video option highlights the snowball effect small choices can have.

\section{Conclusions}

This single case study suggests that drag and LGBT issues are of interest to Japanese high school EFL learners and that with proper scaffolding, the language can be made accessible to them. Based on this, I propose that Drag Race can be a powerful CLIL tool to promote awareness of gender and sexual diversity in Japan. In order to do this, teachers should consider their specific curricula and teaching contexts and start small by finding places where such content can fit appropriately (in this study as one of three options in classes outside of the core curriculum). Furthermore, teachers should take precautions by talking to stakeholders, including administrators, colleagues, students, and when possible parents, both before the class (for advice) and after (for feedback). When teachers meet resistance, I encourage them to be strong in their convictions by questioning why such content is considered inappropriate and brainstorming how it can be successfully adapted and presented. The timidity and narrow-mindedness of some administrators cannot be obstacles to nurturing self-confident LGBT youth and effective allies.

\section{Limitations}

The main limitation of this study is that all participants elected to learn about drag, meaning most students were probably already supportive of LGBT issues. This likely skewed the results positively. Furthermore, although response papers were not assessed 
for content, students may have been more likely to write positive reactions to please their teacher. More unbiased and precise measures targeting all students are needed to more accurately understand students' learning outcomes. Finally, the survey questions may not be a reliable way to gather data on students' understanding of drag, as students self-reported their responses. Moreover, it is not clear whether the feeling of increased understanding was a result of the minilecture, video, or a combination of the two. From this, all that can be said with certainty is that students seemed to believe that they gained more knowledge about drag through the full unit.

\section{Further Research}

Through CLIL or through L1 instruction, LGBT education in Japan needs to be expanded beyond the scope of this study to primary schools for greater impact. In order to do that responsibly, we need to better understand how to reach students who do not choose to learn about LGBT-related content if it is not compulsory. To that end, it might be fruitful to ask the students who did not choose Drag Race why they made a different choice and to investigate ways to engage them more deeply in LGBT content. If we can propose best practices to reach these students and to make teachers more comfortable in introducing such content in class, we may see less reluctance to bringing LGBT content to class and more LGBT representation in EFL materials. The positive effects this would have for gender and sexual minorities cannot be overstated.

\section{Note}

1. Gia Ishikawa had not yet come out as transgender at the time of this class.

\section{Bio Data}

Michael Ellis is the EFL program coordinator at International Christian University High School. He is interested in teachers' reflective practice (among many other topics) and is currently program chair of TD SIG. <maikeru.desu@gmail.com>

\section{References}

Berk, R. A. (2009). Multimedia teaching with video clips: TV, movies, YouTube, and mtvU in the college classroom. International Journal of Technology in Teaching \& Learning, 5(1).
Blackburn, M. V., \& Smith, J. M. (2010). Moving beyond the inclusion of LGBT-themed literature in English language arts classrooms: Interrogating heteronormativity and exploring intersectionality. Journal of Adolescent \& Adult Literacy, 53(8), 625-634. https://doi.org/10.1598/ jaal.53.8.1

Goldstein, B. (2015). LGBT invisibility in language learning materials. Language Issues: The ESOL Journal, 26(2), 35-40.

Ismaili, M. (2013). The effectiveness of using movies in the EFL classroom-A study conducted at South East European University. Academic Journal of Interdisciplinary Studies, 2(4), 121.

MacDonald, S. (2015a). Exploring LGBT lives and issues in adult ESOL: Part one. Language Issues: The ESOL Journal, 26(1), 43-49.

MacDonald, S. (2015b). Exploring LGBT lives and issues in adult ESOL: Part two. Language Issues: The ESOL Journal, 26(2), 27-34

Moore, A. R. (2016). Inclusion and exclusion: A case study of an English class for LGBT learners. TESOL Quarterly, 50(1), 86-108. https://doi.org/10.1002/tesq.208

Murray, N. (Director). (2009). RuPaul's drag race [Television series]. New York, NY: VH1.

Murray, N. (Director). (2014, March 17). Shade: The rusical [Television series episode]. In RuPaul's drag race. New York, NY: VH1.

Nelson, C. D. (2015). LGBT content: Why teachers fear it, why learners like it. Language Issues: The ESOL Journal, 26(1), 6-12.

Ohmori, A. (2014). Exploring the potential of CLIL in English language teaching in Japanese universities: An innovation for the development of effective teaching and global awareness. The Journal of Rikkyo University Language Center, 32, 39-51.

Qiang, N., Hai, T., \& Wolff, M. (2007). China EFL: Teaching with movies. English Today, 23(2), 3946. https://doi.org/10.1017/s0266078407002076

Smolkin, L. B., \& Young, C. A. (2011). Missing mirrors, missing windows: Children's literature textbooks and LGBT topics. Language Arts, 88(3), 217.

Straut, D., \& Sapon-Shevin, M. (2002). "But no one in the class is gay": Countering invisibility and creating allies in teacher education programs. In R. M. Kissen (Ed.), Getting ready for Benjamin: Preparing teachers for sexual diversity in the classroom (pp. 29-42). Lanham, MA: Rowland and Littlefield.

Thein, A. H. (2013). Language arts teachers' resistance to teaching LGBT literature and issues. Language Arts, 90(3), 169-180.

World Economic Forum. (2017). The global gender gap report. Author. Retrieved from https:// www.weforum.org/reports/the-global-gender-gap-report-2017 